\title{
To Follow a Rule: The construction of student subjectivities on classroom rules charts
}

\begin{abstract}
Rules charts are commonplace on classroom walls throughout the world. This paper examines how such charts work to sustain discursive power relationships among teachers and students by mobilising idealised notions of the student within the classroom. The paper reports on a discourse analysis of 50 rules charts and identifies three disciplinary and subjectivising discourses mobilised by charts: the Apollonian 'good', Dionysian 'bad', and Athenian 'choice-making' student. The paper argues that awareness of the constitutive effects of discourse can enable practitioners to reflect on how their discursive practices might have material impacts on students' capacity to move through educational spaces, and in particular can work to marginalise already disenfranchised students who do not fit the normative mould.
\end{abstract}

classroom management; behaviour management; sociology of childhood; school rules; visual discourse analysis; student subjectivities

\section{Introduction}

Schools sustain longstanding institutional power relationships among students, teachers, staff and parents through the banal - but certainly not benign - discursive practices that take place within their walls. Such practices include the use of mundane managerial, organisational, pedagogic and disciplinary texts that produce educational subjectivities (Saltmarsh and Youdell, 2004; Devine, 2002). While processes of subjectification of 
school students are unavoidable, questions of how that subjectification takes place and for whom remain important in order to understand the sorts of subjectivities that are welcomed and excluded on school grounds. The analysis of the ways power operates within educational assemblages is particularly important because it can highlight the processes that sustain historical marginalisation of non-normative bodies. Indeed, there is now a substantial body of evidence highlighting that schools' power structures sustain ongoing discursive marginalisation of students of colour, non-normative genders, working-class backgrounds and disabilities (Youdell, 2006; Millei and Cliff, 2010; Saltmarsh and Youdell, 2004; Gilliam and Gulløv, 2017). This paper focuses on one such disciplinary text - the classroom rules chart - and explores its role in sustaining institutional power relationships. It explicates how classroom rules charts not only work to orient students to behaviours conducive to learning, but also work to produce idealised notions of doing 'student' within educational assemblages.

Foucault's (1977) reading of power is instrumental to this analysis. For Foucault, discursive power relations have the effect of cajoling subjects into acting to situate themselves as intelligible subjects within assemblages of power in order that they benefit from the flow-on effects of normativity. Following from this reading of power, classroom rules charts are viewed here as instrumental in sending normalising messages about how various subject positions 'fit' within school power hierarchies. Similarly, they can send messages about ways students can act upon themselves that are 
socially and educationally rewarding. Thus, to 'follow a rule' is in effect to position oneself within educational assemblages in ways that enable the subject to move through educational spaces with relative impunity.

Youdell's (2006, 2011) work on applying Foucault's (1977) and Butler's (1997) theories of the subjectivising power of educational discourse is also informative here. Following Foucault, Youdell (2006: 34) highlights how the idealised student subjectivities produced within educational assemblages are sustained by their "ongoing constitution in and by discourse". Significantly, "it is the very act of designation that constitutes the subject" (Youdell, 2006: 34), making teachers' discursive practices an important subject of inquiry. This perspective does not negate a priori "enduring institutional discourses about who students are" (Youdell, 2006: 37) which precede the act of designation, but it also emphasises the role of everyday classroom practices in reinscribing student subjectivities and their position within such institutional discourses, inasmuch as "to continue to be recognisable", student subjectivities "must continue to be cited" (Youdell, 2006: 27) in the banal discourses of the classroom.

The study that this paper reports on involves a visual discourse analysis of classroom rules charts shared by teachers online and focusses on the ways students are discursively constituted through those charts. Inspired by Jenks' (2005) work on discourses of childhood, the study examines three dominant discourses of the student that emerge from the corpus, named the Apollonian 'good', Dionysian 'bad' and 
Athenian 'choice-making' students (Jenks, 2005; Smith, 2011). In the analysis below, each of the discursive formations identified are explored, with consideration for how they have the capacity to, in the words of Youdell (2006: 36), "make some things possible, or even likely" within the space of the classroom, while making "other things all but impossible".

\section{Constituting the student through 'rules'}

Schools are spaces in which children of the nation are compulsorily groomed to be particular kinds of moralising, enterprising, competitive and productive bodies (Ball, Maguire and Braun, 2012; Burke, 2011). The ideal of the school as a civilising institution is an explicit theme across formal education policy frameworks in the UK (Ball, Maguire and Braun, 2012; Burke, 2011), Australia (Johnson and Sullivan, 2016; Wardman, 2016), Ireland (Devine, 2002), Denmark (Gilliam and Gulløv, 2017) and elsewhere. Within school spaces, civilising rules are not only deployed through explicit policies, but also the less overt 'hidden curriculum' of schooling (Gilliam and Gulløv, 2017; Thornberg, 2009; Apple, 2004; Morris, 2005) which extends beyond the policies themselves, and into the everyday interactions between and among staff and students. Scholars have explored the power relations involved in the discursive construction of students in everyday interactions such as during physical education classes (Saltmarsh and Youdell, 2004), bathroom breaks (Millei and Cliff, 2014), uniform checks (Burke, 2011; Morris, 2005), special education classes (Thomson and Pennacchia, 2016; 
Youdell, 2011), timetabling and reward systems (Burke, 2011; Ball, Maguire and Braun, 2012; Devine, 2002), and so on. Such interactions reveal not only how student subjectivities are produced through educational discourse, but also how power is enacted in ways that often entrench the exclusion of already disenfranchised groups (Meilli and Cliff, 2014; Youdell, 2006).

Much of this scholarly work on the discursive constitution of the student examines how 'good' and 'bad' student subjectivities are constructed through educational discourse (Burke, 2011; Llamas, 2006; Ball, Maguire and Braun, 2012). The 'good' student norm contains within it an ideal body who knows their place within the power structures of schools, who knows when to speak, what to say and how to say it, what to wear and how to wear it, and all in ways that conform to 'appropriate' gendered (Raby, 2010), raced (Morris, 2005), sexed (Robinson and Davies, 2008), and classed (Keddie, 2007) student subjectivities. The everyday rules, both hidden and explicit, that produce idealised notions of the student are executed in ways that are not only about persuading students to 'act good', but also about demonstrating the rewards that flow from the embodiment of idealised 'good' student subjectivities - social recognition, increased leniency, subtle smiles and nods, and so forth.

One of the more silent but pervasive ways in which school rules work to constitute the student is through their visual representations on the walls of schools. Informative here are Ball, Maguire and Braun (2012) whose work examines the posters 
plastered in highly visible locations of UK schools. To Ball, Maguire and Braun, school posters are both "calls to achievement" (2012: 127) for students - constant silent reminders of the right ways of 'doing' student - but also image management strategies designed to project an idea that this school is one of the 'good schools' for 'good students'. Thus, "structures of signification" such as posters on walls act as "authoritative resources" (Devine, 2002: 306) that work to produce normative knowledge about when and how 'good' students should move through educational assemblages. Alongside organisational and pedagogic documents such as curricula, policy texts and timetables (Ball, Maguire and Braun, 2012; Devine, 2002), rules charts are silent but nonetheless pervasive texts through which idealised educational subjectivities are inscribed into discourse.

In this study, it is this role of banal imagery and text in producing student subjectivities that is at issue, with a focus on the everyday classroom rules charts plastered on classroom walls. By looking at classroom rules charts, the study highlights how schools' posters have the potential to feed into discourse in silent but pervasive ways. Following visual discourse analysis (Van Leeuwen, 2008), this study of the multimodal constitution of discourse is concerned with how the images and text on rules charts have the potential to construct discourse "by suggestion, by connotation, by appealing to barely conscious, half-forgotten knowledge" (Van Leeuwen, 2008: 136). 
The next section considers how the texts in this study were gleaned and analysed using a visual discourse analysis methodology.

\section{Methodological Considerations}

A corpus of rules charts was initially gathered through internet searches using the phrases 'classroom rules chart', 'classroom anchor chart' and 'classroom rules poster'. The charts gleaned through web searches came from a variety of sources including teacher blogs from North America, the UK, New Zealand and Australia, as well as the image sharing site Pinterest, online stores Etsy and Amazon, and the blog site of Scholastic, an international education company. While most classroom rules charts did not identify age groups, those that did signalled that they were for lower primary school aged children, with just three exceptions that indicated the charts could be applied in US middle schools. Many charts were shared by teachers themselves who had produced them for and with their own classes, while others were glossy texts produced and printed for profit. All were included for analysis. The decision was made to stop the search once 50 images were collected in order to sustain a corpus size that both captured a substantial range of texts but also a manageable number for close qualitative analysis (O’Rielly and Parker, 2013).

Following data collection, the charts were explored with a focus on both written and graphic elements. The texts were approached with the assistance of the visual 
analysis methods deployed by Kress and van Leeuwen (2006) whose 'grammar' of visual design enables informed and rigorous readings of words and images. Using their grammar of visual design, the first pass of the texts involved familiarisation with the narratives of the charts, taking notes on how the student was constructed through language (metaphor, synecdoche, synonym, word choice, declarative statements, and so on; see Fairclough, 2013) and imagery (soft, hard, earthy colour schemes, modality, theme, directionality, and so on; see Kress and van Leeuwen, 2006). The focus during the first pass was to ask what key narrative was being told about the 'ideal' student subjectivity through each chart. While visual discourse analysis provides a grammar for closely engaging with images and text, researcher subjectivity is inherent in conducting qualitative work, and in the interest of transparency URLs for the location of all texts are provided in the footnotes in the following pages.

Themes coagulated during a second pass over the texts when charts with common narratives about student subjectivities were grouped and compared. The three themes that emerged from the second pass closely mirrored three metaphors outlined by Jenks (2005) and Smith (2011) in their descriptions of cultural and historical discourses of childhood. The analysis below therefore explores the themes with the assistance of Jenks and Smiths' metaphors: Dionysian (wilful, unruly), Apollonian (good, innocent) and Athenian (intelligent, agentive) constructions of the student.

\section{Civilising Dionysus: cultivating the body and the suppression of revelry}


Named for Dionysus, the Greek god of revelry (Jenks, 2005), the Dionysian construction of student subjectivity envisages students as comported towards disorder and wilfulness. The thirteen charts within this theme framed students in paternalistic ways by primarily working to constrain and civilise an imaginary 'unruly' student in need of discipline. A common structure across the charts that mobilise a Dionysian discourse of the student is the use of command-form phrases (Fairclough, 2013) that target anticipated disorderly behaviour of students in the space of the classroom. Take these commonplace suggestions from a blog on classroom rules charts:

1. Listen And Follow Directions

2. Raise Your Hand Before Speaking Or Leaving Your Seat

3. Respect Your Classmates And Your Teacher

4. Keep Hands, Feet, And Objects To Yourself ${ }^{1}$

A surface reading of these phrases might compel a reader to empathise or agree with a teacher's assessment that students do indeed need reminders of how to listen, follow directions and respect personal space. It could reflect the everyday challenges inherent in managing the affairs of a group of young students. But phrases such as those above that anticipate wilful and devious behaviour (physical aggression, disrespect towards peers) also continue the "citational chain" (Butler, 2011: 282) that makes the unruly Dionysian student not only recognisable, but normative at the level of discourse and expected within the space of the classroom.

\footnotetext{
${ }^{1}$ See the blog piece at: https://www.smartclassroommanagement.com/2009/08/17/the-only-classroomrules-youll-ever-need/
} 
The discursive reach of the Dionysian construct of the student is all the more pervasive given that several of the charts for this study emerged online as templates and even purchasable posters on sites like Etsy and Amazon. Given their catch-all construction, such charts render a discourse of the unruly student as normative across educational assemblages around the English-speaking world. Indeed, the blog post from which the four rules above were gleaned suggests that these rules are ideal precisely because they can function universally, to cast a broad net for catching students' misbehaviour. Discussing the four rules, the blogger advises teachers to "make sure your rules cover every eventuality"2 . Here, the author constructs children as, in the words of Murphy, having "a bias towards evil" (2007: 107) which needs to be anticipated, even before the child is encountered, in order to manage the imagined student's future misbehaviour. Indeed, the choice of term 'eventuality' involves the projection of an image of the unruly student into the future, constituting the student as unruly through a priori discursive imaginings. Similarly, it implies that the discursively 'good' teacher is one who has the capacity to hold power and control close by employing 'authoritative resources' (Devine, 2002) that cast their net wide and claim authority over every aspect of unruly students' lives.

\footnotetext{
${ }^{2}$ See: https://www.smartclassroommanagement.com/2009/08/17/the-only-classroom-rules-youll-everneed/
} 
Furthermore, one of the more persistent strategies within rules charts that construct the Dionysian student, is to civilise students' unruly body parts. With the goal of bodily control and refinement, rules charts often use arrows that work as vectors drawing the eyes (Kress and Van Leeuwen, 2006) to limbs and facial features in order to apply actionable goals ('sit still', 'sitting flat legs crossed', 'eyes on the book', 'belly button forward' 3 , 'listening ears' 4 , 'raise your hand' ${ }^{5}$ ). Similarly, several of the charts dissect body parts through the dismembered pieces of a Mr Potato Head toy ${ }^{6}$, with toy body parts glued to the chart beside commands for each appendage. These charts construct students' bodies as “problem bodies" (Millei and Cliff, 2014: 245) which are in need of discipline. Such attempts at discipline echo Foucault's (1977) claims that western institutions tend to exercise power through the surveillance of bodies within a demarcated space. While Foucault's work on disciplinary power at the level of the body explores prisons, he suggests it is equally applicable to educational institutions. Others have taken up this challenge, examining how schools aim to "rework the behaviour and appearance of students so their bodies display acceptable, normative comportment" (Morris, 2005: 27). In this sense, schools function as "civilising spaces" (Millei and

\footnotetext{
${ }^{3}$ See for these four examples: https://www.scholastic.com/teachers/blog-posts/genia-connell/anchorcharts-classroom-management/

${ }^{4}$ See: https://www.etsy.com/listing/150100294/class-rules-shabby-chic-typographysign?ref=sr_gallery_41\&ga_hp_ref=primary\&ga_search_query=teacher+classroom\&ga_order=most_rele vant\&ga_view_type $=$ gallery\&ga_page $=16 \&$ ga_search_type $=$ all

${ }^{5}$ See: https://www.scholastic.com/teachers/blog-posts/michelle-sullenberger/simple-ideas-forestablishing-classroom-rules-and-manners/

${ }^{6}$ See: http://colorsandkindergarten.blogspot.co.uk/search/label/Classroom\%20Management
} 
Cliff, 2014: 245) in which students' problem bodies are ordered, diagnosed and civilised — made into 'docile bodies' (Foucault, 1977) — in the name of moving students from disorderliness to orderliness, wilfulness to refinement.

Importantly, the body parts that are the target of action are precisely those that students use for making meaning of their surrounds: eyes, ears, mouths, hands, feet and bottom. Therein, such charts attempt to define when, where and how students might be allowed to use their bodies to exercise agency (Fingerson, 2009; Leavitt and Power, 1997). To prevent a student from touching or squirming, or to regulate how and when their listening and speaking is to take place, is to direct when and how students are to learn about their surrounding environment, and indeed how to make sense of themselves as students.

These physical constraints of ostensibly unruly students would likely work to further disenfranchise working-class children in particular, given the extensive academic knowledge about the mismatch between working-class children's use of their bodies for learning and schooling's cultural expectations of learning bodies (Maddock, 2006). Similarly, the commands for bodily constraint continue to 'other' non-normative students with additional physical needs, including children with ADHD and autism, from educational spaces. Here, then, the charts re-inscribe in institutional discourse the demarcations between privileged bodies and historically marginalised bodies, for all children to see. Such charts thus reaffirm a construction of the non-normative student as 
innately disorderly, in need of regulation to foster the right sort of bodily comportment for the right sort of learning; or at least, for the type of learning that happens 'here', in the civilising classroom environment.

The examples above show how Dionysian discourses of the student can be mobilised through rules charts that attempt to constrain and limit unruliness and civilise students' 'problem bodies' (Millei and Cliff, 2014). The Dionysian discourse, when mobilised through classroom rules charts, works to structure students' embodied experiences through idealising the sorts of constrained bodies that reflect the civilised, 'learned', student, and simultaneously, marginalise curious, wriggly subjectivities that are both anticipated and discouraged. However, they not only reveal a predisposition to envisage the student as innately unruly, predisposed to mischief and in need of civilisation, but also function as tools for teachers and students to discern between 'bad' disorderly students and 'good' well-cultivated students. The student with the capacity to embody obedience will one day emerge into adulthood and shake the shackles of predisposed unruliness, given their apprenticeship in denying their innate unruliness is, for now, coming along quite well.

\section{Apollo shines: affirmations of goodness}

Other rules charts, however, tend not to emphasise constraints for unruly students to adhere to, but rather affirmative narratives that cultivate students' innate 'Apollonian' 
goodness within the space of the classroom. The metaphor of Apollo, the god of light and truth, is used by Jenks (2005) to signify the discourse of innate childhood goodness and innocence. Following Jenks, twenty-five charts were identified within the corpus that actively construct Apollonian student goodness. Commonly, this is achieved through declarative phrases (Fairclough, 2013) such as 'we are nice to others" ${ }^{7}$ and 'great classmates are warm-hearted' ${ }^{8}$, using affirmative language to facilitate and draw out childhood goodness. I don't want to suggest that constructions of Apollonian students do not participate in processes of subjectivation; indeed, their discursive effect in constituting students is somewhat similar to the Dionysian constructions discussed above, inasmuch as they form normalising judgements against which students are regulated and made knowable (Youdell, 2011; Butler, 1997). Indeed, like the Dionysian constructions above, Apollonian constructs continue to reinforce paternalistic notions of the student that work to withhold power from students and frame students as incapable of full participation in democratic processes (Sorin and Galloway, 2006). However, the processes of subjectivation that these texts participate in discursively situate the imagined student as one whose embodied goodness is the natural state that needs to be fostered, and is therefore expected.

\footnotetext{
${ }^{7}$ See: http://prekinders.wpengine.netdna-cdn.com/wp-content/uploads/2009/09/class-rules-primarycolors.png

${ }^{8}$ See: https://www.scholastic.com/teachers/blog-posts/genia-connell/anchor-charts-classroommanagement/
} 
What is pervasive across the rules charts that aim to foster an ostensibly innate goodness, is the importance of creating the right sort of 'natural' space for Apollonian students to flourish. Whereas the Dionysian construct implies the behaviour problem lies within the student and emphasises the need for students to 'reform' themselves to fit within the classroom, Apollonian models emphasise reforming the classroom into a natural sanctuary in order to accommodate the 'naturally innocent' student. Following this trope, many of the Apollonian rules charts use graphic cartoon imagery to create thematic classroom spaces that emphasise the connection between the students' childhoods and nature. Wise owls perched on tree branches ${ }^{9}$, monkeys hanging from vines ${ }^{10}$ and other wild animals printed onto rules charts create a sense of a natural animalistic space, uncorrupted by man. The softness of the angles, curves in the branches and low-modality cartoon characters (Kress and Van Leeuwen, 2006) contribute to the theme of a gentle, natural, enchanted space for these students in need of coddling. Indeed, several classrooms rules charts from the corpus were nailed onto trees $^{11}$ or written in the centre of sunflower templates ${ }^{12}$, invoking the correlation between childhood and nature.

\footnotetext{
${ }^{9}$ See: https://clipartfest.com/download/650f7011e5a5f671 ed73d210714daae9e012ca56.html ${ }^{10}$ See: https://www.teacherspayteachers.com/Product/Behavior-Chart-Monkey-Theme-Behavior-ClipChart-Classroom-Decor-864080

${ }^{11}$ See: https://uk.pinterest.com/pin/374854368960598002/

${ }^{12}$ See: http://www.sparklebox.co.uk/gallery/gal41-45/gal43.html\#.WM7rKTvyjIX
} 
Here, two common metaphors of Apollonian student emerge: firstly, that any disorderly behaviour does not lie innately within the student. Students' transgressions of affirmative rules can be easily forgiven ('We do I'm sorry', 'we do mistakes', 'we do growing $\left.{ }^{13}\right)$, inasmuch as any transgressions are at least in part a result of an incongruence between the student's needs and an environment that has not been appropriately cultivated for them (Murphy, 2007). Secondly, the need to moderate the safe space for the student invokes Fröbel's 'kindergarten' (children's garden) or similarly Holt's (1975) 'walled garden' in which a child will flourish. Man's corruption is kept at bay, and animals and nature are emphasised to create a sense of student growth amongst nature. The garden is the fragile womb where goodness 'grows' uncorrupted, and the teacher's role is to tend to its needs:

The adult carer/teacher is the 'gardener' providing all the necessary elements to ensure a healthy, happy child (plant) while also guarding the child from any imminent dangers such as invasions or pollutants that may contaminate or harm the fragile organism.

(Malone, 2007, 515)

To this end, several teacher blogs that were scoured during this study also posted garden themed rules like 'never stop growing' that were designed to be hung on the doors of the classroom ${ }^{14}$ to delineate the safe, well-tended space within from the corruptions of the outside 'adult' world.

\footnotetext{
${ }^{13}$ See: https://www.teacherspayteachers.com/Product/WOODLAND-animals-Classroom-Decor-XLARGE-BANNER-In-Our-Class-We-are-Family-1678697

${ }^{14} \mathrm{See}$ : http://myclassroomideas.com/never-stop-growing-spring-door-decoration/
} 
While arguably the vision of students across the corpus of Apollonian rules charts is a gentler one than those in the Dionysian charts, issues of power and subjectification remain pervasive. The constant claims of 'we are...' and focus on enchanted comic book style imagery works to constantly remind students not to subvert this carefully tendered enchanted discourse. They are not to 'rock the boat', or perhaps more aptly, 'shake the tree', lest they fall outside of the 'good' student subjectivity. There remains a need for students to exercise techniques of the self (Foucault, 1988) in order to embody the narrative made out for them so that they might access the privileges of the 'good' student subjectivity. Such a paternalistic narrative reminds students that dissent or disagreement with the sorts of knowledges privileged within educational spaces will have them excluded from the tendered garden that has been created for them, for the good of the purity of this discourse. The 'good' docile bodies in these spaces remain privileged, and there remains a sense that "compliant students should not have to tolerate non-compliant students" (Sullivan, 2016: 1) who disturb this Garden of Eden.

It is worth questioning, then, what 'shaking the tree' would look like within these spaces: particularly in an era where a girl's failure to conform to gender norms can regularly be rendered 'nasty', a boy's interest in dress-ups uncouth, or a coloured child's dissenting opinion troublemaking (Robinson and Davies, 2008). Furthermore, as with the Dionysian charts, children with visible non-normative physical needs such as 
students with ADHD and autism are more likely to not match the images of 'innocence' or 'constraint' constructed by the charts and thereby continue to be singled out as 'out of place'. Students whose personal narratives are an uneasy fit with dominant classroom discourses can be easily omitted by these Apollonian discourses of the 'good' student (Robinson and Davies, 2008; Ball, Maguire and Braun, 2012). Through silences by omission, the application of Apollonian discourses still works to sustain hierarchies between the 'good' conforming students, and the dissenting 'problem' bodies who are carefully rendered out of place in the classroom's delicately constructed walled garden.

So far, this paper has presented two discourses of the student emergent from classroom rules charts: Apollonian and Dionysian. Both discourses work to enable and foreclose particular ways of constructing student subjectivities within the classroom, variously projecting future visions of students as uncivilised, destructive or innocent, which send messages about how students should be seen and see themselves as social actors. It would be remiss, however, to overlook those charts in this study that emphasise students' participation and choice, and which mobilise an 'empowered' student discourse that has been resurgent in the past two decades as part of the children's rights movement. The next section therefore approaches the 'Athenian' student subjectivity that has been identified in nine charts, named following Smith (2011) after Athena, the goddess of wisdom.

\section{Athena's voice: responsibilised children and the self-governing classroom}


The Athenian discourse of the choice making, self-governing child has been particularly pervasive following the 1989 United Nations Convention on the Rights of the Child (United Nations General Assembly, 1989) that highlights the need for children's participation in decisions regarding their own governance. Furthermore, for scholars such as Rose (1990), the rise of child responsibilisation — and Smith's Athenian child—is in part the result of neoliberal reforms of the past several decades, which have systematically shifted social responsibility from the social democratic post-WWII state onto the individual in wide-ranging areas of public life (Rose, 1990). In educational contexts, the individualisation of responsibility has its antecedents in neoliberal educational reforms that frame students as responsible for their own behaviour. Wardman (2016: 311), for example, has written on the ways neoliberal policies have influenced Australian schools to move away from "responsibility grounded in notions of ethics" and instead to devolve "responsibility for learning, behaviour, as well as institutional and social order" to students themselves. This works to engender school cultures in which students' capacity for self-regulation is heavily scrutinised, and the blame for transgressions individualised (Wardman, 2016; Liljestrand and Hammarberg, 2017).

A key way in which the Athenian construction of the student manifests itself in rules charts is through allowing students to participate in the 'democratic' creation of class rules. This is evident in the student-created rules charts which are often framed as 
a class 'constitution' ${ }^{15}$ or 'promise" ${ }^{16}$. Such charts involve teacher-directed brainstorming of rules before charts are formally written up with the input and consent of students. By ostensibly ceding control over the creation of rules charts, teachers mobilise an Athenian discourse which anticipates students' innate ability for selfgovernment and democratic decision making.

While a discourse of 'freedom' might be invoked by teachers in the creation of democratic rules charts, in practice democratic classrooms tend not to replace teacher dominance with student freedom but with the maternalistic concepts of teacher guidance and facilitation (Millei and Raby, 2010). In this sense, democratic rule-making tends to be heavily reliant on scaffolding to keep "the consequence of not making the "right choice' in focus" (Millei and Raby, 2010: 35). Students are, in this sense, scaffolded into naming the 'right' answers - the answers that deliver the rewards that come from situating the self appropriately within the normative power hierarchies of educational assemblages. The end product of democratic rules charts, therefore, tends to remain a formalised and teacher-influenced normative rules framework to which all students in the class must adhere given that they have registered their compliance. Take the blog post associated with one 'constitution' in this study:

\footnotetext{
${ }^{15}$ See: https://www.scholastic.com/teachers/blog-posts/alycia-zimmerman/we-people---constitutionalapproach-classroom-rules/

${ }^{16}$ See: http://mchinn92.tumblr.com/
} 
On the first day of school we sit down as a class and make our own classroom rules. These rules are created during a discussion by the students, while being facilitated by me. Surprisingly, student created rules are often the same as - or even tougher than rules a teacher might create. The rules the students create become the standard for expected behavior by which all students agree. ${ }^{17}$

In classrooms such as the one described above that mobilise the Athenian selfgoverning student discourse, a student's failure to meet the normative standards they ostensibly set for themselves can be framed as a student's personal failure to live up to standards set by their peers (Rose, 1990; Smith, 2011). Such individualisation of responsibility is even more pervasive in the democratic classroom rules charts which involve pictures of individual students bordering the "promise' ${ }^{18}$, or individualised sheets of paper with each student's promise glued to the chart to show by way of proximity (Kress and van Leeuwen, 2006) that each student has, individually, agreed to the normative conditions of the classroom ${ }^{19}$. The blurb below one image that pictures a student signing the rules chart exemplifies this coerced agreement:

While signing our Class Constitution, all of the students hopefully take ownership of its ideals. ${ }^{20}$

This Athenian discursive formation can therefore have very real impacts for how nonnormative students who contravene 'democratic' norms can come to see themselves as personally culpable, failures, and inept in educational settings. Here, I refer directly

\footnotetext{
${ }^{17}$ See: http://mrsterhune.blogspot.co.uk/2012/07/the-ultimate-classroom-tour.html

18 See: http://mchinn92.tumblr.com/

${ }^{19} \mathrm{https}$ //www.scholastic.com/teachers/blog-posts/genia-connell/anchor-charts-classroom-management/

${ }^{20} \mathrm{See}$ : https://www.scholastic.com/teachers/blog-posts/alycia-zimmerman/we-people---constitutionalapproach-classroom-rules/
} 
again to students whose non-normative comportments tends to place them outside of group behavioural norms in educational assemblages: children with additional physical or learning needs; or children who stand out based on racial, social class and gender characteristics. For these children, disciplinary power remains, albeit now projected back upon the student twice over given the student is not only contravening institutional rules, but ostensibly personal and social ones too. As Smith (2011:20) argues, "the idea of child or youth 'participation' is deployed more as a tool for constituting particular kinds of selves ... than promoting a broader role for children in society".

Therein, the charts that mobilise the Athenian student discourse work to generate student subjectivities that are responsibilised and choice-making, and at the same time actively work to foreclose notions of student innocence inasmuch as the student is now considered entirely culpable for their own actions. Such charts also reveal how the mobilisation of the Athenian student discourse engages in processes of normative subjectivisation by constructing non-normative students as personally culpable for their lack of conformity. This can have the effect of masking the role of social structures such as social class, gender and race hierarchies in producing educational inequalities. All rules charts explored in this study, then, produce normative messages about how to 'do' student subjectivity in the space of the classroom, and send messages about how students should be seen, and see themselves, as social actors.

\section{Conclusions}


If teachers' everyday discursive practices work to "produce and regulate the subject" (Butler, 1997: 143), then the discursive constructions of student subjectivity that they mobilise have consequences for how students in classrooms can come to understand and relate to themselves. This paper has highlighted how some rules charts produce students as innately wilful, others as innately good and pure. Still others produce students as choice-makers, yet nonetheless all three discursive formations explored here have been found to subjectify students and send messages about what students 'are' and their place within the power structures of educational assemblages.

While it is hard to imagine a way of constituting schooling without disciplinary procedures that subjectify students, questioning how that subjectification takes place matters for understanding the exclusions and inclusions that it engenders (Sorin and Galloway, 2006). Thus, this paper has highlighted how rules construct some ways of 'doing' a student subjectivity legible and render other possible student subject positions 'out of place' in the educational context. As this paper has argued, the subject positions the charts tend to marginalise are those that are already historically marginalised: gendered, raced, classed and sexed subjectivities that do not meet norms set-out by dominant discourses of the ideal student. This is particularly concerning for those students with additional educational needs - ADHD, autism, tourette's syndrome, and so on - who are further marginalised by the existence of charts on walls that consistently remind them that they do not belong. Such charts do the subtle work of teaching these 
students that without self-regulation, their wriggly, nasty or discomforting bodies won't reap those same rewards. Through semiotic means, rules posters recreate inequalities not only through the blunt instrument of classroom rules, but more subtly, through the student discourses that those rules sustain. 
Apple M (2004) Ideology and Curriculum. New York: RoutledgeFalmer.

Ball S, Maguire M and Braun A (2012) How schools do policy: Policy enactments in secondary schools. London: Routledge.

Burke J (2011) Call out the troops: classrooms, discipline and authority. In: Dillon J and Maguire M (eds) Becoming a teacher: Issues in secondary education. London: McGraw-Hill, pp.185-196.

Butler J (1997) Excitable speech: A politics of the Performative. New York: Routledge.

Butler J (2011) Bodies that matter: On the Discursive Limits of Sex. London: Taylor and Francis.

Devine D (2002) Children's citizenship and the structuring of adult-child relations in the primary school. Childhood 9(3): 303-320.

Fairclough N (2013) Critical discourse analysis: The critical study of language. London: Routledge.

Fingerson L (2009) Children's bodies. In: Qvortrup J, Corsaro W and Honig M (eds) The Palgrave Handbook of Childhood Studies. London: Palgrave Macmillan, pp. 217-227.

Foucault M (1977) Discipline and Punish: The Birth of the Prison. London: Penguin.

Foucault M (1988) Technologies of the Self. In: Martin L, Gutman J and Hutton P (eds) Technologies of the Self: A Seminar with Michel Foucault. Amherst: University of Massachusetts Press, pp. 16-49.

Gilliam L and Gulløv E (2017) On civilising: a perspective on childrearing, conduct and distinctions. In: Gilliam L and Gulløv E (eds) Children of the welfare state: civilising practices in schools, childcare and families. London: Pluto Press, pp. $8-31$.

Holt J (1975) Escape from Childhood: The Needs and Rights of Children. New York: Dutton.

Jenks C (2005) Childhood. Oxon USA: Routledge.

Johnson B and Sullivan A (2016) Understanding and Challenging Dominant Discourses about Student Behaviour at School. In: Sullivan A, Johnson B and Lucas B (eds) Challenging Dominant Views on Student Behaviour at School: Answering Back. Singapore: Singer, pp. 27-44. 
Keddie A (2007) Games of subversion and sabotage: issues of power, masculinity, class, rurality and schooling British Journal of Sociology of Education 28(2): 181-194.

DOI: $10.1080 / 01425690701192596$

Kress G and van Leeuwen T (2006) Reading Images: The Grammar of Visual Design. London: Routledge.

Leavitt R and Power M (1997) Civilizing bodies: children in day care. In: Tobin J (ed) Making Place for Pleasure in Early Childhood Education. New Haven: Yale University Press, pp. 39-75.

Liljestrand J and Hammarberg A (2017) The social construction of the competent, selfgoverned child in documentation. Contemporary Issues in Early Childhood 18(1): 39-54.

Llamas J (2006) Technologies of disciplinary power in action: The norm of the 'Good student' Higher Education 52(4): 665-686.

Maddock M (2006) Children's personal learning agendas at home. Cambridge Journal of Education 36(2): 153-169.

Malone K (2007) The bubble-wrap generation: children growing up in walled gardens. Environmental Education Research 13(4): 513-527.

Millei Z and Cliff K (2014) The preschool bathroom: Making 'problem bodies' and the limit of the disciplinary regime over children. British Journal of Sociology of Education 35(2): 244-262.

Millei Z and Raby R (2010) Embodied logic: understanding discipline through constituting the subjects of discipline. In: Millei Z, Griffiths R and Parkes R (eds) Re-Theorizing Discipline in Education. New York: Peter Lang, pp. 27-42.

Morris E (2005) Tuck in that shirt!' Race, class, gender, and discipline in an urban school. Sociological Perspectives 48(1): 25-48.

Murphy E (2007) Images of childhood in mothers' accounts of contemporary childrearing. Childhood 14(1): 105-127.

O’Reilly M and Parker N (2013) 'Unsatisfactory Saturation': a critical exploration of the notion of saturated sample sizes in qualitative research. Qualitative research 13(2): 190-197. 
Raby R. (2010) 'Tank tops should be ok but I don't want to see her thong': girls, dress codes and the regulation of femininity Youth and Society 41(1): 333-356.

Robinson K and Davies C (2008) Docile bodies and heteronormative moral subjects: Constructing the child and sexual knowledge in schooling. Sexuality \& Culture 12(4): 221-239.

Rose N (1990) Governing the Soul: The Shaping of the Private Self. London: Taylor and Francis.

Saltmarsh S and Youdell D (2004) 'Special sport' for misfits and losers: educational triage and the constitution of schooled subjectivities. International Journal of Inclusive Education 8(4): 353-371.

Smith K (2011) Producing governable subjects: Images of childhood old and new. Childhood 19(1): 24-37.

Sorin R and Galloway G (2006) Constructs of childhood: Constructs of self. Children Australia 31(2): 12-21.

Sullivan A (2016) Introduction: Why It Is Important to Answer Back. In: Sullivan A, Johnson B and Lucas B (eds) Challenging Dominant Views on Student Behaviour at School: Answering Back. Singapore: Singer, pp. 1-14.

Thomson P and Pennacchia J (2016) Hugs and behaviour points: Alternative education and the regulation of 'excluded' youth. International Journal of Inclusive Education 20(6): 622-640.

Thornberg R (2009) The moral construction of the good pupil embedded in school rules. Education, Citizenship and Social Justice 4(3): 245-261.

United Nations General Assembly. (1989). Convention on the Rights of the Child. New York, NY: United Nations. Available at: http://www.ohchr.org/en/professionalinterest/pages/crc.aspx

Van Leeuwen T (2008) Discourse and practice: New tools for critical discourse analysis. Oxford: Oxford University Press.

Wardman N (2016) 'Productive' and 'disciplined' students for the 'common good': Globalised discourses of neoliberal and neoconservative responsibility in Australian education policy. Global Studies of Childhood 6(3): 311-323.

Youdell D (2006) Diversity, inequality, and a post-structural politics for education. Discourse: Studies in the cultural politics of education 27(1): 33-42. 
Youdell D (2011) School Trouble: Identity, Power and Politics in Education. London: Routledge. 